\title{
Lung Sound Analysis Is Useful for Monitoring Therapy in Patients With Bronchial Asthma
}

\author{
Shimoda $T^{1}$, Obase $Y^{2}$, Nagasaka $Y^{3}$, Nakano $\mathrm{H}^{1}$, Kishikawa R1', Iwanaga $\mathrm{T}^{1}$ \\ ${ }^{1}$ Clinical Research Center, Fukuoka National Hospital, Fukuoka, Japan \\ 2Department of Respiratory Medicine, Nagasaki University Graduate School of Biomedical Sciences, Nagasaki, \\ Japan \\ ${ }^{3}$ Kyoto Respiratory Center, Otowa Hospital, Kyoto, Japan
}

J Investig Allergol Clin Immunol 2017; Vol. 27(4): 246-251

doi: 10.18176/jiaci.0132

\begin{abstract}
Background: Lung sound analysis (LSA) has been reported to be useful for predicting airway obstruction and inflammation in patients with bronchial asthma.

Objectives: We examined whether the exhalation-to-inhalation sound pressure ratio in the middle frequency range (200-400 Hz) (E/l MF) is useful for monitoring therapy in patients with asthma.

Methods: The study population comprised 84 patients with mild to moderate asthma whose LSA data were available before and after 1 year of daily treatment with (budesonide $800 \mu \mathrm{g}$ ). We analyzed whether the E/I MF before and after treatment was associated with the fractional exhaled nitric oxide (FeNO) level, sputum eosinophil percentage, respiratory function, and airway hyperresponsiveness.

Results: Prior to treatment with budesonide, the E/I MF was significantly correlated with respiratory function, airway hyperresponsiveness, FeNO, and sputum eosinophil percentage. The cutoff values for the E/l MF to detect the abnormalities of respiratory function, FeNO, and sputum eosinophil percentage were $0.367,0.358$, and 0.363 , respectively. With respect to the reference value, the E/l MF improved significantly in patients whose respiratory function and FeNO benefited from therapy with budesonide compared with patients whose respiratory function did not benefit from budesonide (odds ratios of 6.39 and 4.78 , respectively). According to the multivariate analysis, patients whose $\mathrm{E} / \mathrm{MF}$ did not improve had a longer history of smoking $(P=.038)$, poorer posttreatment respiratory function $(P=.028)$, and higher posttreatment FeNO $(P=.0095)$.

Conclusion: Similar to respiratory function and FeNO, E/I MF based on LSA is a useful indicator for monitoring the efficacy of therapy in asthmatic patients.
\end{abstract}

Key words: Bronchial asthma. Fractional exhaled nitric oxide. Induced sputum. Inhaled corticosteroid. Lung sound analysis.

\section{Resumen}

Introducción: El análisis de los sonidos pulmonares ha demostrado ser una prueba de utilidad para objetivar la presencia de obstrucción e inflamación en las vías respiratorias de pacientes con asma bronquial.

Objetivos: Hemos evaluado si el cociente sonido inspiración-espiración por presión en el rango de frecuencias medias, de 200 a $400 \mathrm{~Hz}$, (E/l MF) tenía utilidad en la evaluación de la respuesta al tratamiento en pacientes con asma bronquial.

Métodos: El estudio incluyó 84 pacientes con asma leve o moderada que tuvieran registros de LSA antes y tras un año de tratamiento con $800 \mu \mathrm{g}$ de budesonida inhalada. Analizamos si los cambios en E/l MF tras el tratamiento se correlacionaban con los cambios en los niveles de óxido nítrico en aire exhalado (FeNO), el porcentaje de eosinófilos en muestras de esputo inducido, la función pulmonar y la hiperreactividad bronquial.

Resultados: Antes de iniciar el tratamiento con budesonida inhalada, el cociente E/I MF se correlacionaba significativamente con la función pulmonar, la hiperreactividad bronquial, los niveles de FeNO y el porcentaje de eosinófilos en las muestras de esputo. Los puntos de corte del cociente E/I MF para detectar valores anómalos en la función pulmonar, los niveles de FeNO, y el porcentaje de eosinófilos en esputo eran $0,367,0,358$ y 0,363 respectivamente. El cociente E/l MF mejoraba significativamente en el grupo de pacientes en los que la budesonida inhalada inducía cambios significativos en la función pulmonar o en los niveles, con respecto a los valores de referencia apropiados comparados con los de los grupos de pacientes que no presentaban mejoría en estos parámetros (odds ratios de 6,39 y 4,78, respectivamente). En un análisis multivariante los pacientes que no presentaban mejoras significativas en el cociente E/I MF presentaban una 
historia de tabaquismo activo significativamente más larga $(\mathrm{p}=, 038)$, unos niveles de función pulmonar tras tratamiento significativamente más bajos ( $\mathrm{p}=, 028)$, y paralelamente unos niveles de FeNO, tras tratamiento, más elevados $(\mathrm{p}=, 0095)$.

Conclusiones: Al igual que la función pulmonar y los niveles de FeNO, el cociente E/l MF obtenido mediante el LSA es un indicador útil para evaluar la eficacia del tratamiento en pacientes con asma bronquial.

Palabras clave: Asma bronquial. Fracción de óxido nítrico en aire exhalado. Esputo inducido. Corticoide inhalado. Análisis de sonidos pulmonares.

\section{Introduction}

Abnormal breath sounds are audible when a change in lung structure alters sound transmission: sounds that are not normally heard may become audible, or sounds that are normally heard may become inaudible [1]. Lung sounds are generally considered to arise from thickened airways between the trachea and the ninth division of the bronchioles and are transmitted through the lung parenchyma, including the alveoli, and the chest wall before they are heard upon auscultation [2,3]. Detection of abnormal breath sounds on auscultation requires experience and may occasionally be difficult. Lung sound analysis (LSA), on the other hand, has advantages, including greater sensitivity than auscultation and the ability to conduct objective recording. We apply LSA when evaluating patients with bronchial asthma, regardless of the sound type. LSA is performed by adjusting airflow. When lung sounds are monitored with inspiratory airflow maintained at a constant level, patients with bronchial asthma exhibit a higher median frequency of inspiratory sound (F50) than healthy individuals, and the F50 increases as airway obstruction becomes more severe [4]. Even in patients with bronchial asthma and no audible adventitious breath sounds, F50 increases and forced expiratory volume in 1 second $\left(\mathrm{FEV}_{1}\right)$ decreases in response to histamine challenge $[5,6]$. However, it is difficult to ensure the same inspiratory flow in patients with bronchial asthma, because the severity of asthma varies from patient to patient.

We previously performed a study of nonsmoking corticosteroid-naive patients in the interictal period of bronchial asthma and reported that the exhalation-to-inhalation sound pressure ratio in the low frequency (LF) range $(100-200 \mathrm{~Hz})$ (E/I LF), a parameter detected using LSA, was strongly correlated with airway inflammation [7]. Furthermore, we used new software capable of removing noise (EasyLSA) to analyze bronchial asthma patients before therapy and confirmed that the exhalation-to-inhalation sound pressure ratio in the middle frequency (MF) range $(200-400 \mathrm{~Hz})(\mathrm{E} / \mathrm{I} \mathrm{MF})$ was more strongly correlated with airway inflammation, obstruction, and hyperresponsiveness than E/I LF [8]. No previous studies have indicated that the EI sound pressure ratio in a specified frequency range, such as $\mathrm{E} / \mathrm{I} \mathrm{MF}$, is useful as an indicator in the treatment of bronchial asthma.

In the present study, we examined how E/I MF was correlated with fractional exhaled nitric oxide (FeNO), sputum eosinophil percentage, respiratory function, and airway hyperresponsiveness to assess whether E/I MF is useful for monitoring the efficacy of therapy in patients with bronchial asthma.

\section{Methods}

\section{Patients and Study Design}

The study population comprised 84 patients for whom LSA data were available before and after 1 year of treatment with inhaled corticosteroids (ICS) (budesonide $800 \mu \mathrm{g} / \mathrm{d}$ ). The patients were selected from among patients with mild to moderate bronchial asthma who were treated as new patients at our hospital between 2003 and 2013 and who were willing to participate in our study. We performed LSA, blood tests, pulmonary function tests, FeNO measurement, an acetylcholine bronchial provocation test, and induced sputum analysis. All the patients included in this study fulfilled the GINA criteria [9] and had a history of asthma symptoms (including recurrent cough, wheezing, and dyspnea) and exhibited positive airway hyperresponsiveness $\left(\mathrm{PC}_{20}\right.$ for acetylcholine $<8 \mathrm{mg} / \mathrm{mL}$ ). Patients with conditions complicated by chronic pulmonary obstructive disease (COPD) and patients with cardiopulmonary disease that affected pulmonary function were excluded. All patients retained normal diffusion capacity. No patients had previously used an inhaled or oral corticosteroid. The use of antiasthma drugs, including bronchodilators, was discontinued for at least 24 hours prior to the examination. Wheezing was not detected on auscultation in any patient.

The ethics committee of Fukuoka National Hospital approved the study protocol (protocol No.: 20-12), and all participants received verbal and written information about the study before providing their informed consent.

\section{Lung Sound Analysis}

Lung sound recording was performed in a quiet room (although not in a soundproof booth) in the outpatient department. The patients breathed deeply during the breath sound recording. Lung sounds were recorded using a handheld microphone for $\geq 30$ seconds over the left lung base. The recording system consisted of an electronic stethoscope containing a wide-range audio sensor attached to a diaphragm (Bio-Sound Sensor BSS-01, Kenz Medico), a signal processing unit, and a personal computer. The sensor used a band-pass filter range of 40-2500 Hz and displayed good sound-collecting ability in the $40-2000 \mathrm{~Hz}$ range. The recorded sound was analyzed using a sound spectrometer (Easy-LSA, Nakano), before being resampled to $5012 \mathrm{~Hz}$, analyzed via fast Fourier analysis, and displayed as a spectrogram, with frequency in hertz on the vertical axis and time in seconds on the horizontal axis. The recording system was calibrated with a reference 
sound pressure $(1 \mathrm{kHz} ; 94 \mathrm{~dB}[0 \mathrm{~dB}=20 \mu \mathrm{Pa}])$. One breath with relatively little noise was chosen by visual observation, and average sound intensity during inhalation and expiration was analyzed in the 200-400-Hz frequency range. We defined this frequency range to be the MF range and determined the inspiration sound pressure level in the MF range (I MF), expiration sound pressure level in the MF range (E MF), and $\mathrm{E} / \mathrm{I} \mathrm{MF}$, for which data were converted from logarithmic values to real values.

\section{Other Examinations}

Flow-volume curves were generated, FeNO and airway hyperresponsiveness to acetylcholine were measured, and sputum was induced and processed in accordance with previously reported procedures $[7,8,10,11]$.

\section{Statistical Analysis}

The correlations between E/I MF and various test parameters related to bronchial asthma before and after treatment with ICS were analyzed using Spearman rank correlation coefficients. The cutoff values for the E/I MF were compared between the airway obstruction-positive and -negative groups, which were stratified using an $\mathrm{FEV}_{1} / \mathrm{FVC} \%$ threshold of $70 \%$, a FeNO threshold of $21 \mathrm{ppb}$, and a sputum eosinophil percentage of $3 \%$ based on the receiver operating characteristic curve analysis [12]. The proportion of patients with a pretreatment E/I MF below the cutoff value and the proportion of patients with a pretreatment $\mathrm{E} / \mathrm{I} \mathrm{MF}$ at or above the cutoff were determined. Subsequently, patients were further classified as having normalized or nonnormalized E/I MF. Posttreatment data separated by cutoff values, including the spirogram results, $\mathrm{PC}_{20}, \mathrm{FeNO}$, and eosinophil percentage, were compared between the normalized and nonnormalized groups using the $\chi^{2}$ test. Multiple regression analyses (least squares method) were performed to identify factors related to the differences between the normalized and nonnormalized groups.

\section{Results}

\section{Patient Characteristics}

Age ranged from 16 to 72 years, with a mean $(95 \% \mathrm{CI})$ of 43.7 (40.6-46.8) years; there were 47 females and 37 males. The patient cohort included 51 nonsmokers, 16 ex-smokers, and 17 current smokers with a mean smoking rate of 6.06 (1.31-3.44) packs/year. The mean $(95 \% \mathrm{CI})$ of the tested parameters was $91.7 \%(88.4 \%-94.9 \%)$ for $\mathrm{FEV}_{1 \% \text { predicted }}, 2.74$ (2.62-2.85) for $\log \mathrm{PC}_{20}, 90.6$ (72.1-109.1) ppb for FeNO, and $16.8 \%(12.1 \%-21.5 \%)$ for the sputum eosinophil percentage (Table 1).

Table 1. Patient Characteristics

\begin{tabular}{|c|c|c|c|c|c|c|}
\hline & & \multicolumn{2}{|c|}{ Before Treatment } & \multicolumn{2}{|c|}{ After Treatment } & \\
\hline & & Mean & $(95 \% \mathrm{CI})$ & Mean & $(95 \% \mathrm{CI})$ & \\
\hline Age, y & & 43.7 & $(40.6-46.8)$ & & & \\
\hline Body mass index, $\mathrm{kg} / \mathrm{m}^{2}$ & & 22.7 & $(22.0-23.4)$ & & & \\
\hline Sex, female/male & $47 / 37$ & & & & & \\
\hline Severity, mild persistent/moderate persistent & $74 / 10$ & & & & & \\
\hline Allergic rhinitis, no/yes & $42 / 42$ & & & & & \\
\hline Atopic dermatitis, no/yes & $70 / 14$ & & & & & \\
\hline Atopic/nonatopic & $53 / 29$ & & & & & \\
\hline Nonsmoker/ex-smoker/current smoker & $51 / 16 / 17$ & & & & & \\
\hline Pack-years & & 6.06 & $(1.31-3.44)$ & & & \\
\hline Asthma duration, $\mathrm{y}$ & & 6.5 & $(4.5-8.4)$ & & & \\
\hline $\mathrm{FEV}_{1} / \mathrm{FVC} \%$ & & 74.8 & $(72.6-77.0)$ & 78 & $(76.5-79.6)$ & * \\
\hline $\mathrm{FEV}_{1 \% \text { predicted }}$ & & 91.7 & $(88.4-94.9)$ & 98.8 & $(96.2-101.4)$ & ** \\
\hline V50\%predicted & & 63.1 & $(57.5-68.7)$ & 73 & $(67.8-78.3)$ & * \\
\hline V25\%predicted & & 49.6 & $(44.0-55.2)$ & 56.1 & $(51.1-61.2)$ & \\
\hline $\log \mathrm{PC}_{20}$ & & 2.74 & $(2.62-2.85)$ & 3.32 & $(3.20-3.44)$ & $* *$ \\
\hline FeNO, ppb & & 90.6 & $(72.1-109.1)$ & 35.8 & $(28.6-43.1)$ & $* *$ \\
\hline Sputum eosinophils, \% & & 16.8 & $(12.1-21.5)$ & 3.6 & $(1.9-5.3)$ & $* *$ \\
\hline $\mathrm{E} / \mathrm{I} \mathrm{MF}$ & & 0.44 & $(0.40-0.48)$ & 0.34 & $(0.31-0.37)$ & $* *$ \\
\hline
\end{tabular}


Correlations Between E/l MF and Spirogram Results, $P C_{20}$, FeNO, and Sputum Eosinophil Percentage Before and After Treatment With ICS

Before treatment, E/I MF exhibited significant negative correlations with $\mathrm{FEV}_{1} / \mathrm{FVC} \%, \mathrm{FEV}_{1 \% \text { predicted, }}$ V50\% $\%_{\text {predicted, }}$, and $\log \mathrm{PC} 20\left(\mathrm{r}_{\mathrm{s}}=0.34,-0.38,-0.36\right.$, and -0.29 , respectively $)$ and significant positive correlations with FeNO and the eosinophil percentage ( $\mathrm{rs}=0.31$ and 0.38 , respectively). In contrast, after treatment, E/IMF exhibited negative correlations with $\mathrm{FEV}_{1} / \mathrm{FVC} \%$ and $\mathrm{V} 5 \%_{\% \text { predicted }}\left(\mathrm{r}_{\mathrm{s}}=0.45\right.$ and -0.49 , respectively) and positive correlations with $\mathrm{FeNO}$ and the eosinophil percentage ( $\mathrm{rs}=0.41$ and 0.33 , respectively), but not with $\mathrm{FEV}_{1 \% \text { predicted }}$ or $\log \mathrm{PC}_{20}$ (Table 2). The decrease in $\mathrm{E} / \mathrm{I} \mathrm{MF}$ correlated with the decrease in $\mathrm{FeNO}\left(\mathrm{r}_{\mathrm{s}}=0.28\right)$.

\section{EII MF Cutoff Value for Airway Inflammation and Obstruction}

The E/I MF cutoff values were 0.367 using an $\mathrm{FEV}_{1} / \mathrm{FVC} \%$ threshold of $70 \%, 0.358$ using a FeNO threshold of $21 \mathrm{ppb}$, and 0.363 using a sputum eosinophil percentage threshold of $3 \%$; all $3 \mathrm{E} / \mathrm{I} \mathrm{MF}$ cutoff values were similar (Figure).

\section{Comparison of E/l MF Normalization Ratios After Treatment With ICS}

The E/I MF was normalized to less than 0.37 after treatment with ICS and was significantly correlated with the normalized $\mathrm{FEV}_{1} / \mathrm{FVC} \%(\mathrm{P}=.005), \mathrm{V} 50_{\% \text { predicted }}(P=.004)$, and $\mathrm{FeNO}$ $(P=.01)$. There were no significant correlations between the

Table 2. Correlations Between the E/l MF and the Spirogram Findings, $\mathrm{PC}_{20}$, FeNO, and Sputum Eosinophil Percentage Before and After Treatment

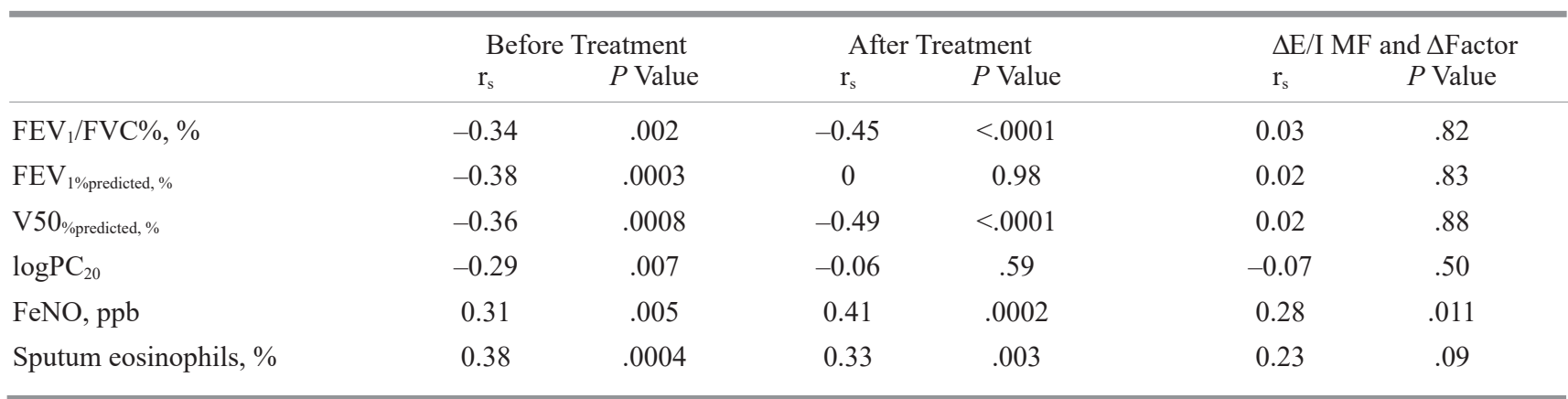

Abbreviations: E/l MF, exhalation-to-inhalation sound pressure ratio in the middle frequency (MF) range (200-400 Hz); FeNO, fractional exhaled nitric oxide; FEV 1 , forced expiratory volume in 1 second; FVC, forced vital capacity.

A

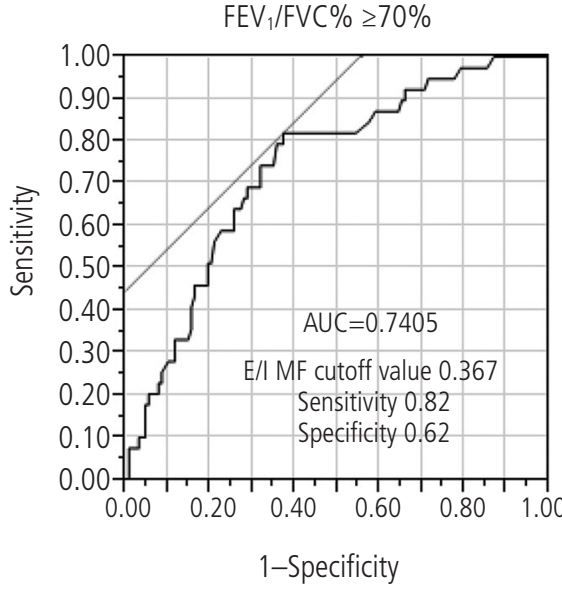

B

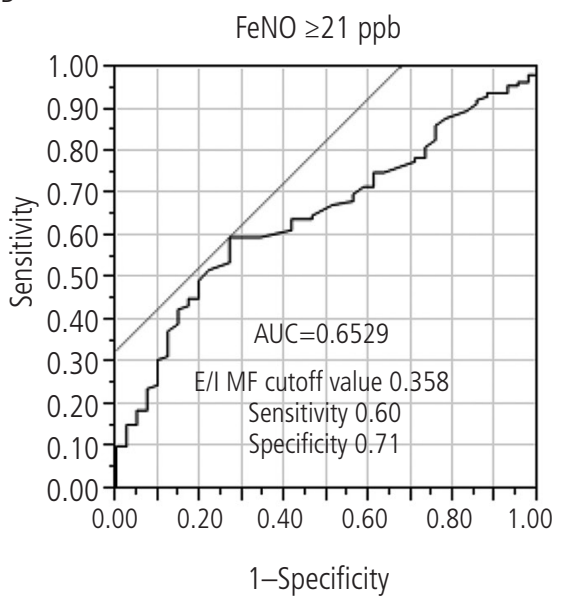

C

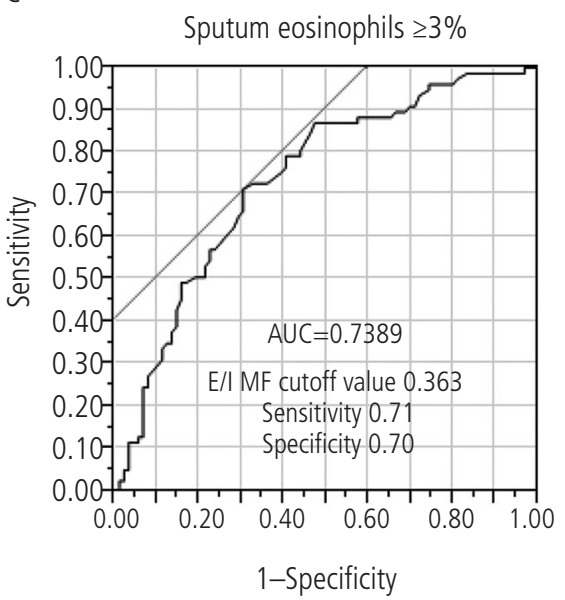

Figure. E/I MF cutoff value for airway inflammation and obstruction (receiver operating characteristic curve). A, When the data are stratified as FEV1/ FVC $\% \geq 70 \%$ or $<70 \%$, the E/I MF cutoff value is 0.367 , with a sensitivity of 0.82 and a specificity of 0.63 . B, When the data are stratified using a FeNO $\geq 21 \mathrm{ppb}$ or $<21 \mathrm{ppb}$, the E/I MF cutoff value is 0.358 , with a sensitivity of 0.60 and a specificity of 0.71 . C, When the data are stratified as sputum eosinophil percentage $\geq 3 \%$ or $<3 \%$, the E/l MF cutoff value is 0.363 , with a sensitivity of 0.71 and a specificity of 0.70 . E/l MF indicates exhalation-to-

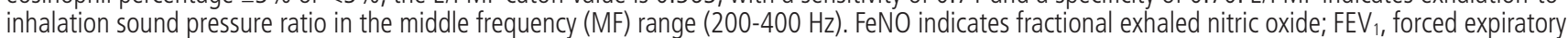
volume in 1 second; FVC, forced vital capacity. 
Table 3. Comparisons of the Normalized E/I MF Rates After Treatment With Inhaled Corticosteroids

\begin{tabular}{|c|c|c|c|}
\hline & $\begin{array}{c}\text { Normalized } \\
\text { Percentage } \\
\text { (Yes/No) }\end{array}$ & $P$ Value & $\begin{array}{l}\text { Odds Ratios } \\
\quad(95 \% \mathrm{CI})\end{array}$ \\
\hline \multicolumn{4}{|l|}{$\mathrm{FEV}_{1} / \mathrm{FVC} \%$} \\
\hline$\geq 70 \%$ & $68.1(49 / 23)$ & & \\
\hline$<70 \%$ & $25.0(3 / 9)$ & .005 & $6.39(1.58-25.85)$ \\
\hline \multicolumn{4}{|l|}{$\mathrm{FEV}_{1 \% \text { predicted }}$} \\
\hline$\geq 80 \%$ & $63.6(49 / 28)$ & & \\
\hline$<80 \%$ & $42.9(3 / 4)$ & .28 & $2.33(0.49-11.19)$ \\
\hline \multicolumn{4}{|l|}{ V50\%predicted } \\
\hline$\geq 80 \%$ & $85.2(23 / 4)$ & & \\
\hline$<80 \%$ & $50.9(29 / 28)$ & .004 & $5.55(1.70-18.10)$ \\
\hline \multicolumn{4}{|l|}{$\mathrm{PC}_{20}$} \\
\hline$\geq 8000 \mu \mathrm{g} / \mathrm{mL}$ & $61.2(41 / 26)$ & & \\
\hline$<8000 \mu \mathrm{g} / \mathrm{mL}$ & $64.7(11 / 6)$ & .79 & $0.86(0.28-2.61)$ \\
\hline \multicolumn{4}{|l|}{ FeNO } \\
\hline$<21 \mathrm{ppb}$ & $81.5(22 / 5)$ & & \\
\hline$\geq 21 \mathrm{ppb}$ & $51.9(27 / 25)$ & .01 & $4.07(1.34-12.40)$ \\
\hline \multicolumn{4}{|c|}{ Sputum eosinophils } \\
\hline$<3 \%$ & $67.8(40 / 19)$ & & \\
\hline$\geq 3 \%$ & $45.8(11 / 13)$ & .06 & $2.49(0.94-6.57)$ \\
\hline
\end{tabular}

Abbreviation: $E / I M F$, exhalation-to-inhalation sound pressure ratio in the middle frequency (MF) range (200-400 Hz).

rate of $\mathrm{E} / \mathrm{I} \mathrm{MF}$ normalization and $\mathrm{FEV}_{1} \%$ predicted or $\log \mathrm{PC}_{20}$ values after treatment with ICS (Table 3 ).

\section{Factors Related to the Differences Between the E/I MF Values in the Normalized and Nonnormalized Groups After Treatment With ICS Based on the Multiple Regression Analysis}

According to the multiple regression analysis, the nonnormalized posttreatment $\mathrm{E} / \mathrm{I} \mathrm{MF}$ group had a longer smoking history $(P=.038)$, a lower posttreatment V50\% $(P=.028)$, and a higher posttreatment FeNO $(P=.010)$ (Table 4).

\section{Discussion}

In this study, decreases in E/I MF were correlated with decreases in FeNO during treatment with ICS. E/I MF may represent the relationship between the 2 mechanisms influenced by ICS, namely, enhancement of expiratory and inspiratory sound pressure, which depends on an increase in respiratory flow, and a mechanism related to the alteration of respiratory sound transmission from the sound source due to changes in asthmatic airway conditions as a result of reduced inflammation and dilation of the airway after treatment.
Table 4. Factors Related to the Differences Between the E/l MF Values of the Normalized and Nonnormalized Groups After Treatment With Inhaled Corticosteroids

\begin{tabular}{lcccc}
\hline & Estimate & SE & $\chi^{2}$ & $P$ Value \\
\hline FEV $_{1} / \mathrm{FVC}^{2}$ & & & & \\
Age, y $(\mathrm{N})$ & 0.002 & 0.038 & 0 & .96 \\
Pack-years (N) & -0.010 & 0.048 & 4.3 & .038 \\
Posttreatment V50\%predicted (N) & 0.075 & 0.034 & 4.85 & .028 \\
Posttreatment FeNO (N) & -0.080 & 0.031 & 6.73 & .010
\end{tabular}

Abbreviations: N, normalized; SE, standard error.

abased on the multiple regression analysis. Parameters that showed a significant difference based on the univariate analysis were selected and tested using the least squares method.

Administration of bronchodilators improves respiratory function and reduces tracheal sound spectral power [13].

With respect to the sounds heard on auscultation, the amplitude is proportional to the square of the flow rate, and the tracheal sound power is proportional to the fourth power of the flow rate $[14,15]$. We speculate that treatment with ICS reduced airway inflammation and increased airway lumen diameter, which in turn increased the respiratory flow volume and rate upon deep breathing. As a result, patients with normalized $\mathrm{E} / \mathrm{I} \mathrm{MF}$ exhibited an increase in I MF. The same mechanism appears to account for the positive correlation between inspiratory sound intensity and $\mathrm{FEV}_{1 \% \text { predicted, }}$, consistent with the report by Bohadana et al [16]. Asthma-induced airway narrowing alters sound transmission from the source and enhances expiration sound pressure and frequency; appropriate treatment reduces expiratory sound pressure.

The results demonstrated a significant correlation between pretreatment $\mathrm{E} / \mathrm{I} \mathrm{MF}$ and airway obstruction, hyperresponsiveness, and inflammation, as well as a significant correlation between posttreatment E/I MF and peripheral airway obstruction and airway inflammation. However, no correlation was observed between posttreatment E/I MF and central airway obstruction or airway hyperresponsiveness. Thus, E/I MF may be affected by peripheral airway obstruction and airway inflammation.

Because $\mathrm{FEV}_{1} / \mathrm{FVC} \%$, FeNO, and sputum eosinophil percentage were found to correlate significantly with E/I MF both before and after treatment with ICS, the cutoff value for E/I MF was examined after stratifying the study data using known cutoff values for these parameters [9,17]. Interestingly, each $\mathrm{E} / \mathrm{I} \mathrm{MF}$ cutoff value used to predict the $\mathrm{FEV}_{1} / \mathrm{FVC} \%$ threshold of $70 \%$, the FeNO threshold of $21 \mathrm{ppb}$, and the sputum eosinophil percentage threshold of $3 \%$ was within a narrow range (0.358 to 0.367$)$. Based on this result, an E/I MF cutoff value of 0.37 was used to divide the patients into the normalized group and the nonnormalized group. $\mathrm{E} / \mathrm{I} \mathrm{MF}$ improved significantly in the groups for which $\mathrm{FEV}_{1} /$ $\mathrm{FVC} \%$, V50\%predicted, and $\mathrm{FeNO}$ improved after treatment with ICS compared with the groups for which these values did not improve (odds ratios of $6.39,5.55$, and 4.07 , respectively). Therefore, E/I MF appears to be able to indicate airway obstruction and airway inflammation before and after treatment. 
Smoking history, residual peripheral airway constriction, and residual airway inflammation were independent risk factors for nonnormalized $\mathrm{E} / \mathrm{I} \mathrm{MF}$.

These characteristics may be attributed to residual neutrophilic airway inflammation related to smoking. As shown in previous reports, an increase in the sputum neutrophil percentage is correlated with airway construction [18], and neutrophilic asthma is associated with a poor response to treatment with ICS [19]. As shown in our previous study, heavier smoking was associated with higher E/I MF levels [8]. Therefore, in patients whose E/I MF does not decrease after treatment with ICS, physicians should also monitor FeNO and/or sputum cell differentiation and other parameters to assess whether airway inflammation is neutrophilic (as in smoking-related inflammation) or eosinophilic. The results may lead them to reconsider their therapeutic strategy.

In conclusion, the presence of airway obstruction and airway inflammation in patients with bronchial asthma is associated with increased E/I MF, which is reduced by treatment with ICS. Similar to FeNO and respiratory function test results, E/I MF based on LSA is a useful parameter for monitoring therapeutic efficacy in patients with bronchial asthma.

\section{Acknowledgments}

The authors would like to thank Miss Oda and Miss Kojima for their technical assistance and for performing the statistical analyses.

\section{Funding}

This study was supported by Fukuoka National Hospital research funding.

\section{Conflicts of Interest}

The authors declare that they have no conflicts of interest.

\section{References}

1. Nagasaka Y. Lung sounds in bronchial asthma. Allergol Int. 2012:61:353-63.

2. Banaszak EF, Kory RC, Snider GL. Phonopneumography. Am Rev Respir Dis. 1973;107:449-55.

3. Forgacs P, Nathoo AR, Richardson HD. Breath sounds. Thorax. $1971 ; 26: 288-95$.

4. Malmberg LP, Pesu L, Sovijärvi AR. Significant differences in flow standardised breath sound spectra in patients with chronic obstructive pulmonary disease, stable asthma, and healthy lungs. Thorax. 1995;50:1285-91.

5. Anderson K, Aitken S, Carter R, MacLeod JE, Moran F. Variation of breath sound and airway caliber induced by histamine challenge. Am Rev Respir Dis. 1990;141:1147-50.

6. Spence DP, Bentley S, Evans DH, Morgan MD. Effect of methacholine induced bronchoconstriction on the spectral characteristics of breath sounds in asthma. Thorax. 1992:47:680-3

7. Shimoda T, Nagasaka $Y$, Obase $Y$, Kishikawa R, Iwanaga T. Prediction of airway inflammation in patients with asymptomatic asthma by using lung sound analysis. J Allergy Clin Immunol Pract. 2014;2:727-32.

8. Shimoda T, Obase $Y$, Nagasaka Y, Nakano $H$, Kishikawa $R$, Iwanaga $T$. Lung sound analysis and airway inflammation in bronchial asthma. J Allergy Clin Immunol Pract. 2016;4:505-11.

9. Global initiative for asthma (GINA). Global strategy for asthma management and prevention. NIH Publication: 02e3659. Bethesda: National Institutes of Health, National Heart, Lung and Blood Institute; 2014.

10. Metso T, Rytilä P, Peterson C, Haahtela T. Granulocyte markers in induced sputum in patients with respiratory disorders and healthy persons obtained by two sputum-processing methods. Resp Med. 2001;95:48-55.

11. Silkoff PE. Recommendations for standardized procedures for the online and offline measurement of exhaled lower respiratory nitric oxide and nasal nitric oxide in adults and children-1999. Am J Respir Crit Care Med. 1999;160:210417.

12. Alvarez-Puebla MJ, Olaguibel Rivera JM, Almudevar $E$, Echegoyen AA, de Esteban Chocarro B, Cambra K. Cutoff point for exhaled nitric oxide corresponding to $3 \%$ sputum eosinophils. J Investig Allergol Clin Immunol. 2015;25:107-11.

13. Fiz JA, Jané $R$, Salvatella $D$, Izquierdo J, Lores L, Caminal $P$, Morera J. Analysis of tracheal sounds during forced exhalation in asthma patients and normal subjects: bronchodilator response effect. Chest. 1999;116:633-8.

14. Yosef M, Langer R, Lev S, Glickman YA. Effect of airflow rate on vibration response imaging in normal lungs. Open Respir Med J. 2009:3:116-22.

15. Shykoff BE, Ploysongsang Y, Chang HK. Airflow and normal lung sounds. Am Rev Respir Dis. 1988;137:872-6.

16. Bohadana $A B$, Peslin $R$, Uffholtz $H$. Breath sounds in the clinical assessment of airflow obstruction. Thorax. 1978;33:345-51.

17. Matsunaga $K$, Hirano $T$, Kawayama $T$, Tsuburai $T$, Nagase $H$, Aizawa H, Akiyama K, Ohta K, Ichinose M. Reference ranges for exhaled nitric oxide fraction in healthy Japanese adult population. Allergol Int. 2010;59:363-7.

18. Simpson JL, Scott R, Boyle MJ, Gibson PG. Inflammatory subtypes in asthma: assessment and identification using induced sputum. Respirology. 2006;11:54-61.

19. Pavord ID, Brightling CE, Woltmann G, Wardlaw AJ. Noneosinophilic corticosteroid unresponsive asthma. Lancet. 1999:353:2213-4

- Manuscript received August 31, 2016; accepted for publication December 19, 2016.

\section{- Terufumi Shimoda}

Clinical Research Center

Fukuoka National Hospital

4-39-1 Yakatabaru, Minami-ku, Fukuoka 811-1394

Japan

E-mail: t-shimoda@mfukuoka2.hosp.go.jp 